\title{
STUDY ON PROBIOTIC AS ANTIBIOTIC REPLACEMENT TO IMPROVE EGG PRODUCTION IN COMMERCIAL DUCK FARMS
}

\author{
Imam Suswoyo ${ }^{1}$ Ismoyowati $^{1}$, Elly Tugiyanti $^{1}$ \\ ${ }^{1}$ Laboratory of Poultry Production Faculty of Animal Science \\ Jenderal Soedirman University Indonesia \\ e-mail: imam.suswoyo@unsoed.ac.id
}

\begin{abstract}
A research has been conducted to study the potency of probiotics as antibiotic replacements in terms of egg production and income over feed cost at commercial duck farms. The treatments were control, probiotic administration $\left(\mathrm{P}_{1}=5\right.$ and $\mathrm{P}_{2}=7 \mathrm{ml} / \mathrm{kg}$ feed $)$, and antibiotic administration $\left(\mathrm{A}_{1}=0.5\right.$ and $\mathrm{A}_{2}=1$ dose). Thus, there were 5 treatment units which were replicated 4 times. Each unit had 30 laying ducks, so in total there were 600 local laying ducks. Parameters observed were egg production as Hen Day Production and egg mass. Hen Day Production was measured by calculating the number of eggs, divided by the number of female ducks in percentage. Egg mass was calculated by the number of eggs multiplied by the weight of the eggs, divided by the number of ducks. The results showed that egg production in control, $\mathrm{P}_{1}, \mathrm{P}_{2}, \mathrm{~A}_{1}$ and $\mathrm{A}_{2}$ was $50.95 \%, 62.90 \%, 60.85 \%, 56.75 \%$ and $65.40 \%$ respectively. For egg mass, the data were $36.07 \pm 3.25 ; 44.58 \pm 3.63 ; 42.64 \pm 4.31 ; 41.44 \pm 3.76$; and $45.27 \pm 4.57$ respectively. Statistical analysis revealed that, for both parameters, there was a significant difference $(\mathrm{P}<0.05)$ between control and treatments but not a significant difference among treatment groups. It seemed that probiotics and antibiotics had similar effects on Hen Day Production and egg mass. It can be concluded that probiotics could replace antibiotic administration for laying ducks in terms of egg production.
\end{abstract}

Keywords: probiotic, antibiotic, egg production, ducks, commercial farms.

\section{Introduction}

The use of antibiotic in poultry farming grew rapidly and even inclined under uncontrollable condition so that antibiotic could be purchased freely in poultry shops. Misuse of antimicrobials through improper licensing and unwatched withdrawal periods are commonly observed in developing countries [1]. There were evidence for a significant effect of antibiotic on growth rates, feed conversion efficiency, or quality of the flock, which are the characteristics of importance in the economics of poultry production [2]. The use of antibiotics in poultry and livestock production is favorable to farmers and the economy as well because it has generally improved poultry performance effectively and economically but at the same time, the likely dissemination of antibiotic resistant strains of pathogenic and nonpathogenic organisms into the environment and their further transmission to humans via the food chain could also lead to serious consequences on public health [3]. As a feed additive, 
antibiotic was administrated in small amount continously with a purpose to prevent pathogenic microbes development. Although antibiotic was given to poultry, the use of antibiotic could affect consumer health [4].

Antibiotic residue, which affects antibiotic resistance, can be found in both meat and eggs of poultry. Antibiotic resistance is of great public health concern because the antibioticresistant bacteria associated with farm animals may be pathogenic to humans, easily transmitted to humans via food chains, and widely disseminated in the environment via animal waste [5]. Antibiotics in animal feed have the potential to cause pathogenic microbes to develop resistance [6], as well as increase the risk of pathogenic bacteria materials being transmitted from poultry to humans [7]. Various antibiotics used in the treatment of animal diseases have been shown to occur in animal products used as human food.

The presence of antibiotics in human food is associated with several adverse public health effects including hypersensitivity, tissue damage, gastrointestinal disturbance, and neurological disorders [8]. Repeated use of antibiotics in poultry diets resulted in severe problems like resistance of pathogen to antibiotics, accumulation of antibiotics residue in their products and environment, imbalance of normal microflora and reduction in beneficial intestinal microflora [9]. Since the mid 2000's many countries has baned antibiotic use as Antibiotic Growth Promotor (AGP), including avilamycin, avoparcin, bacitracin, flavomycin, spiramycin, tylocin, and viginiamycin [10]. Those antibiotics produce residue in poultry products. Nowadays, food safety is one of the global interests, particularly relating to increased virulence as impact of antibiotic use in poultry [11]. The use of natural feed additive, such as probiotic, was an alternative to improved poultry performance as antibiotic replacement. Nowadays, probiotic has been widely used not only for poultry, but also for fishery [12].

Probiotics are known to be beneficial to their host [13]. Probiotics contain yeast cells, bacterial culture, or both, which are capable of stimulating gut microbes to modify the gastrointestine environment to support health status and increase feed efficiency [14]. In probiotic, Lactobacillus $s p$. has several enzymes improve digestion and absorption of nutrients of the host [15]. Saccharomyces cerevisiae is highly advantageous since they are organisms that are immune to the action of antibacterials and they can play an important role by being part of the gut microbiota [16].

Dietary supplementation with probiotics has potential commercial applications for improvements in hen performance and eggshell quality during the early laying period [17]. Probiotic administration improved egg production, shell weight and thickness, and decreased yolk cholesterol content [18]. Previous studies indicated that probiotics increased productivity and welfare of laying ducks [19] [20].

Hen day production was (HDP) was the most important traits in commercial egg laying duck, since HDP directly effected farm income. The other main egg characteristics were mass which represented egg weight produced per duck [21]. This research has been conducted to study the potency of probiotics as antibiotic replacements in terms of hen day production and egg mass at commercial duck farms.

\section{Materials and Method \\ Method}

Experimental method was applied in this research, which has been conducted in collaboration with the 'Berkah Abadi' duck farmer group, which keeps the birds under a dry system intensively. The intensive system refers to the ordinary way done by the farmers in which ducks are confined to the farmer's village with a closed fence so that the birds have no access to the outside area, and the amount of feed provided can be controlled and measured. The farmer group contributed to this research by providing ducks as the main material, as well as 
housing and feed. Daily records were kept for egg production, for both number and weight. The 'Berkah Abadi' farmer group was one of several duck farmers' groups in Tegal City, which is located in the northern plains coastal area of Java Island. The city, which is one of the most important duck centers in Indonesia, is home to a famous local laying duck breed, namely the Tegal Duck. It is believed that the duck belongs to the Indian Runner family.

\section{Materials}

Six hundred local laying ducks (Tegal ducks) at the age of $12.3 \pm 0.9$ months were used. The feedstuffs were locally available and mainly consisted of rice bran, dried rice, and fresh fish (Leiognathidae) with a proportion of $39,65 \%, 25 \%$, and $35 \%$ respectively. The nutrient content was $26,38 \%$ crude protein, $2.923 \mathrm{kcal} / \mathrm{kg}$ metabolic energy, 2,29\% calcium, and $0,78 \%$ phosphorus. Feed was given twice a day, i.e. in the morning and in the afternoon, while drinking water was provided ad libitum three times a day, i.e. in the morning, noon, and afternoon.

The study used a Completely Randomized Design with 3 groups, namely control, probiotic administration $\left(\mathrm{P}_{1}=5\right.$ and $\mathrm{P}_{2}=7 \mathrm{ml} / \mathrm{kg}$ feed $)$, and antibiotic administration $\left(\mathrm{A}_{1}=0.5\right.$ and $\mathrm{A}_{2}=1$ dose). There were 5 treatment units which were replicated 4 times. In total, there were 20 treatment units with 30 laying ducks per unit. The probiotic used was a mix of Lactobacillus sp. and Saccharomyces sp., while the antibiotic administered was amoxitine. Probiotics and antibiotics were thoroughly mixed with the feed, and it was given every morning.

Parameters observed were:

- Hen day production as a percentage of hen day production is measured by calculating the number of eggs divided by the number of female ducks in percentage.

$\mathrm{HDP}=$ (number of eggs/number of female ducks) $\mathrm{x} 100 \%$.

- Egg mass is calculated by the number of eggs multiplied by the weight of the eggs divided by the number of ducks.

$\mathrm{EM}=$ (number of eggs $\mathrm{x}$ weight of eggs) $:$ number of female ducks.

Data obtained was analysed using variance analysis at a $5 \%$ level of confidence.

\section{Results and Discussion}

Average hen day production and egg mass per treatment unit during this study are presented in Table 1

Table 1. Average egg production and egg mass per treatment unit

\begin{tabular}{|l|c|c|c|c|c|}
\hline \multirow{2}{*}{ Parameter } & Control & \multicolumn{2}{|c|}{ Probiotic } & \multicolumn{2}{c|}{ Antibiotic } \\
\cline { 3 - 6 } & & $\mathrm{P}_{1}$ & $\mathrm{P}_{2}$ & $\mathrm{~A}_{1}$ & $\mathrm{~A}_{2}$ \\
\hline $\begin{array}{l}\text { Hen day } \\
\text { prod. (\%) }\end{array}$ & $50.95 \pm 2.57^{\mathrm{a}}$ & $62,90 \pm 2.55^{\mathrm{b}}$ & $60,85 \pm 4.52^{\mathrm{b}}$ & $56,75 \pm 3.79^{\mathrm{b}}$ & $65,40 \pm 5.87^{\mathrm{b}}$ \\
\hline $\begin{array}{l}\text { Egg Mass } \\
\text { (g/bird/day) }\end{array}$ & $36.07 \pm 3,25^{\mathrm{a}}$ & $44.58 \pm 3,63^{\mathrm{b}}$ & $42.64 \pm 4,31^{\mathrm{b}}$ & $41.44 \pm 3,76^{\mathrm{b}}$ & $45.27 \pm 4,57^{\mathrm{b}}$ \\
\hline
\end{tabular}

Note: a different superscript on the same line indicates a significant difference $(\mathrm{P}<0.05)$

\section{Hen Day Production}

During this study, the average egg production per treatment unit ranged from $50.95 \pm 2.552 \%$ to $65,40 \pm 5.87 \%$. These figures were in accordance with previous research [22], which found that the egg production of ducks kept intensively was $64.50 \%$ on average. The lowest egg production was found in the control group, whereas the highest was in $\mathrm{A}_{2}$. Statistical analyses showed that the egg production was significantly different $(\mathrm{P}<0.05)$ between control and treatment groups. These findings confirm previous studies that probiotic administration had higher egg production [19]. Probiotics positively affected production performance, egg 
quality, and blood metabolite parameters in laying hens [23]. Using probiotics as a food supplement improves the intestinal microbial balance of the host. Probiotics cooperate with the host to enhance intestinal immunity and morphology but can also induce metabolism function, thus decreasing the risk of infection by opportunistic pathogenic bacteria [24]. Probiotics had a significant effect on gut anatomy in that they macroscopically extended the chicken gut and microscopically increased gut density and villi. Therefore, probiotics improved gut surface area to absorb nutrients. Probiotics can modulate the ecosystems of intestinal microflora while also producing a natural antibiotic that has the potential to affect the health and performance of the host [25]. Those phenomena, most probably, were the reasons why egg production in probiotic administration was higher than in control.

A similar condition was also found in antibiotic administration. The main purpose of antibiotics is to prevent pathogenic organisms, thus preventing poultry health, as well as to increase feed efficiency and growth through, among others, improving vafourable gut microflora [26]. The antibiotics, as a result, maintained the healthy status of the ducks. It is not surprising, therefore, that egg production under probiotic and antibiotic administration groups was higher than in the control group. The egg production was not significantly different among treatments. It revealed that the use of probiotics and antibiotics had similar effects on egg production. Duck egg production of control and treatment units is presented in Figure 1.

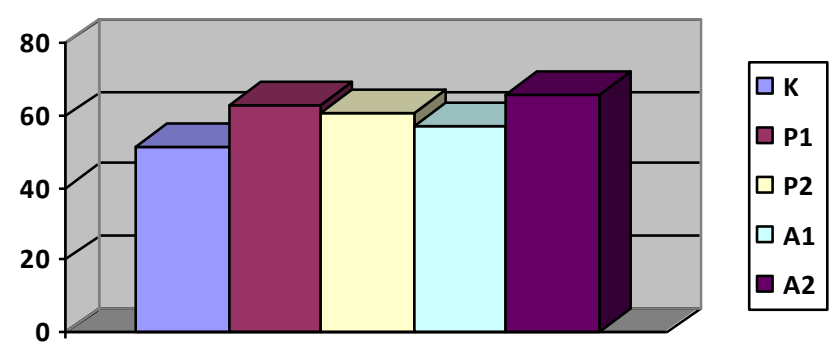

Figure 1. Hen day production of control and treatment units

\section{Egg mass}

The average egg mass was ranging from $36.07 \pm 3,25$ to $45.27 \pm 4,57 \mathrm{~g}$. These figures were in the range of previous research [27] who reported that egg mass was 38 to $51 \mathrm{~g}$. The lowest egg mass was found at control, while the highest was at $\mathrm{A}_{2}$. Statistical analyses showed that egg mass at control unit was significantly different $(\mathrm{P}<0.05)$ compared to that at treamnets units. It indicated that additional probiotic and antibiotic if duck feed has increased egg mass. This result in accordance with [28] who concluded that supplementation of laying duck diets with Saccharomyces sp. increase egg mass. Dietary protein and amino acids, among others, were significant factors affected egg mass [29]. The use of antibiotics promotes the elimination of pathogens from the gastrointestinal tract, and improvement in nutrient absorption, lower energy and protein expenditure, lower mmonia production, and a lower rate of food passage [30]. Among the treatments, however, probiotic and antibiotic had no significant different $(\mathrm{P}>0.05)$. It implies that supplementation probiotic and antibiotic in duck diets had similar effect on egg mass. Figure 2 illustates egg mass during the study. 


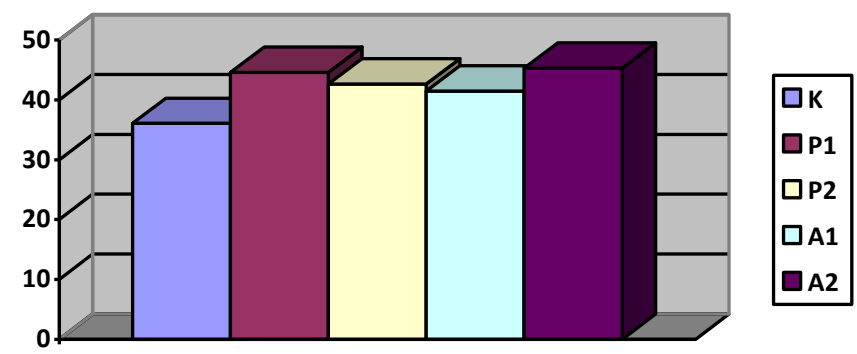

Figure 2. Egg mass of control and treatment units

\section{Conclusion}

Based on the findings of this study, it is possible to conclude that probiotics could replace antibiotic administration in laying ducks in terms of hen day production and egg mass.

\section{Aknowledgment}

The authors deeply acknowledge the financial support from the Rector of Jenderal Soedirman University Indonesia and duck farmers of 'Berkah Abadi Farmer Group' in Tegal for their fruitful collaboration during this study.

\section{References}

[1] Alaboudi, AR. 2017. Antimicrobial Residues in Table Eggs. In: Egg Inovation and Strategies for Improvements. Academic Press.

[2] GRAHAM, J.P. , J.J. BOLAND, AND E. SILBERGELD. Growth Promoting Antibiotics in Food Animal Production: An Economic Analysis. Public Health Rep. 122 (1): 79-87 (2007)

[3] APATA, D.F. Antibiotic Resistence in Poultry. International Jou. of Poul. Sci. 8 (4): 404-408 (2009).

[4] MARKOVIC, R., D. M. SEFER, KRSTIC, AND B. PETRUJKIC. Effect of different growth promoters on broiler performance and gut morphology. Arch. Med. Vet. 41: 163169 (2009).

[5] MANYI-LOH, CH., S. MAMPHWELI, E. MEYER, AND A OKOH. Antibiotic Use in Agriculture and Its Consequential Resistance in Environmental Sources: Potential Public Health Implications. Molecules 23 (4): 795 (2018).

[6] KHACHATRYAN, A.R., T.E. BESSER, D.D. HANCOCK AND D.R.CALL. Use of a nonmedicated dietary supplement correlates with increased prevalence of streptomycinsulfa-tetracycline-resistant Escherichia coli on a dairy farm. Appl. Environ. Microbiol. 72: 4583-4588 (2020).

[7] VAN DER BOGAARD, A.E., N. LONDON, C. DRIESSEN AND E.E. STOBBERINGH. Antibiotic esistance of faecal Escherichia coli in poultry, poultry farmers and poultry slaughterers. J. Antimicrob. Chemoter. 47: 767-771 (2001).

[8] Wassenaar, T. M. (2005). The use of antimicrobial agents in veterinary medicine and implications for human health. Critical Reviews in Microbiology, 31, 155-169.

[9] BARTON, M.D. Antibiotic use in animal feed and its impact on human health. Nutr. Res. Rev., 13: 279-299 (2000).

[10] BRUFAU, J., AND J. TARRADAS. Update of non-antibiotic era in EU. World Poultry Vol. 32 No. 8. p. 72 (2017). 
[11] SOFOS, J.N. Challenges to meat safety in the 21st century. Meat Sci. 78: 3-13 (2008).

[12] HASIM, H., BAIDI, N., SYAMSUDDIN, S., AND TUIYO, R. Administration of Probiotic sanolife Mic-S on Biological Performance of Vanamei Shrimp (Litopenaeus vannamei) PL 10. Technium: Romanian Journal of Applied Sciences and Technology, 3(8), 42-57 (2021).

[13] FULLER R., G.R. GIBSON. Probiotics and prebiotics: microflora management for improved gut health. Clin. Microbiol. Infect. (4): 477-480 (1998).

[14] YORUK, M. A., M. GUL, A. HAYIRLI, AND M. MACIT. The Effects of Supplementation of Humate and Probiotic on Egg Production and Quality Parameters During the Late Laying Period in Hens. Poult Sci. (1):84-8 (2004).

[15] SCHOLZ-AHRENS K.E., P. ADE, B. MARTEN, P. WEBER, W. TIMM, Y. ACIL, C.C. GLUER, J. SCHREZENMEIR. Prebiotics, probiotics, and synbiotics affect mineral absorption, bone mineral content, and bone structure. J. Nutr. (3):137 (2007). Suppl. 2:838S-846S.

[16] FERNANDEZ-PACHECO, P., M. AREVALO-VILLENA, A. BAVILACQUA, M.R COBO, AB PEREZ. Probiotic characteristics in Saccharomyces cerevisiae strains: Properties for application in food industries. LWT - Food Science and Technology (97): 332-340 (2018).

[17] MIKULSKI, D., J. JANKOWSKI, J. NACKMANSKI, M. MIKULSKA, V. DEMEY. Effects of dietary probiotic (Pediococcus acidilactici) supplementation on performance, nutrient digestibility, egg traits, egg yolk cholesterol, and fatty acid profile in laying hens. Poultry Science (10): 2691-2700 (2012).

[18] LALLEMAND, B. 2019. Supporting egg quality through feed solutions. World Poultry Vol. 32 No. 10. pp. 35-37.

[19] SUSWOYO, I., ROSIDI. Welfare and Egg Production of Local Ducks Fed Diets Containing Two Probiotics in Commercial Farms. International Jou. of Poul. Science Vol.15 (6): 235-239 (2016).

[20] SUSWOYO, I., ISMOYOWATI, W. WIDODO, AND Z. VINCĒVIČA-GAILE: The Use of Probiotic and Antioxidants to Improve Welfare and Production of Layer Duck at Commercial Farms for Global Warming Mitigation. E3S Web of Conferences 226, 00025 (2021).

[21] BALKAN, M., M BIRICIK. Main Egg Characteristics In The Peking Duck (Anas platyrhynchos f. dom.). D.U.Ziya Gokalp Egitim Fakultesi Dergisi (11): 142-150 (2008).

[22] SUSWOYO, I., ISMOYOWATI. Study on Duck (Anas plathyrhinchos) Welfare under Extensive and Intensive Systems of Production. International Jou. of Current Research 13 (2): 16047-16049 (2021).

[23] SJOFJAN, O., D.N. ADLI, MM SHOLIKIN, A. JAYANEGARA, A. IRAWAN. The effects of probiotics on the performance, egg quality and blood parameters of laying hens: A meta-analysis. J. Anim. Feed Sci. 30(1):11-18 (2021).

[24] CALY D.L, R. D'INCA, E. AUCLAIR, D. DRIDER. Alternatives to Antibiotics to Prevent Necrotic Enteritis in Broiler Chickens: A Microbiologist's Perspective. Front. Microbiol. 6:1336 (2015).

[25] ZURMIATI, M. E. MAHATA, M. H. ABBAS, WIZNA. The Aplication of Probiotic on Duck (In Indonesian Language). Jurnal Peternakan Indonesia Vol. 16 (2) (2014).

[26] Ministry of Agriculture. 2019. The use of antibiotic in Chicken. Center for Agricultural Extensions. Jakarta.

[27] NURJANNAH, S YANTO, PATANG. Utilization of Golden Snail (Pomacea Canaliculata L) and Waste Crab Shell (Portunus Pelagicus) to Animal Feed for Increase the Production of Egg's Duck. Jurnal Pendidikan Teknologi Pertanian, Vol. 3: 137-147 (2017). 
[28] BIDURA, I.G.N.G., N.W. SITI, D.P.M.A. CANDRAWATI, E. PUSPANI. Effect of Probiotic Saccharomyces spp. on Duck Egg Quality Characteristics and Mineral and Cholesterol Concentrations in Eggshells and Yolks. Pakistan Journal of Nutrition 18: 1075-1083 (2019).

[29] Yurlahmen, R. 2008. Performance of laying hens aged 21-27 weeks under administration of betel leaf stew (Piper battle Linn) (in Indonesian Language). Study Program of Animal Feed and Nutrition. Bogor Agricultural University, Bogor (2008).

[30] DE LIMA, M.R., F.G.P. COSTA, E.B. DE OLIVEIRA, R.G.S. DEMINICIS, D.S. DO NASCIMENTO, T.S. RIBEIRO. Alternatives to the use of antibiotics in egg productions. Open Access J Sci. (5):145-147 (2017).

[1] Alaboudi, AR. 2017. Antimicrobial Residues in Table Eggs. In: Egg Inovation and Strategies for Improvements. Academic Press.

[2] Graham, JP. , JJ. Boland, and E Silbergeld. 2007. Growth Promoting Antibiotics in Food Animal Production: An Economic Analysis. Public Health Rep. 122 (1): 79-87.

[3] Apata, DF. 2009. Antibiotic Resistence in Poultry. International Jou. of Poul. Sci. 8 (4): 404-408.

[4] Markovic, R., D. Šefer, M. Krstic, and B. Petrujkic. 2009. Effect of different growth promoters on broiler performance and gut morphology. Arch. Med. Vet. 41: 163-169.

[5] Manyi-Loh, Ch., S. Mamphweli, E. Meyer, and A Okoh., 2018. Antibiotic Use in Agriculture and Its Consequential Resistance in Environmental Sources: Potential Public Health Implications. Molecules 23 (4): 795.

[6] Khachatryan, A.R., T.E. Besser, D.D. Hancock and D.R.Call. 2020. Use of a nonmedicated dietary supplement correlates with increased prevalence of streptomycinsulfa-tetracycline-resistant Escherichia coli on a dairy farm. Appl. Environ. Microbiol. 72: 4583-4588.

[7] Van Der Bogaard, A.E., N. London, C. Driessen and E.E. Stobberingh. 2001. Antibiotic esistance of faecal Escherichia coli in poultry, poultry farmers and poultry slaughterers. J. Antimicrob. Chemoter. 47: 767-771.

[8] Wassenaar, T. M. (2005). The use of antimicrobial agents in veterinary medicine and implications for human health. Critical Reviews in Microbiology, 31, 155-169.

[9] Barton, M.D. 2000. Antibiotic use in animal feed and its impact on human health. Nutr. Res. Rev., 13: 279-299.

[10] Brufau, J., and J. Tarradas. 2017. Update of non-antibiotic era in EU. World Poultry Vol. 32 No. 8. p. 72.

[11] Sofos, J.N. 2008. Challenges to meat safety in the 21st century. Meat Sci. 78: 3-13.

[12] Hasim, H., Baidi, N. ., Syamsuddin, S., \& Tuiyo, R. . (2021). Administration of Probiotic sanolife Mic-S on Biological Performance of Vanamei Shrimp (Litopenaeus vannamei) PL 10.Technium: Romanian Journal of Applied Sciences and Technology, 3(8), 42-57. https://doi.org/10.47577/technium.v3i8.4581

[13] Fuller R., Gibson G.R. Probiotics and prebiotics: microflora management for improved gut health. Clin. Microbiol. Infect. 1998;4:477-480. doi: 10.1111/j.14690691.1998.tb00401.x

[14] Yoruk, M. A., M. Gul, A. Hayirli, and M. Macit. 2004. The Effects of Supplementation of Humate and Probiotic on Egg Production and Quality Parameters During the Late Laying Period in Hens.

[15] Scholz-Ahrens K.E., Ade P., Marten B., Weber P., Timm W., Açil Y., Glüer C.C., Schrezenmeir J. Prebiotics, probiotics, and synbiotics affect mineral absorption, bone mineral content, and bone structure. J. Nutr. 2007;137(3) Suppl. 2:838S-846S. doi: 10.1093/jn/137.3.838S.

[16] Fernandez-Pacheco, P., M. Arevalo-Villena, A. Bavilacqua, MR Cobo, AB Perez. 2018. 
Probiotic characteristics in Saccharomyces cerevisiae strains: Properties for application in food industries. LWT - Food Science and Technology 97 (2018) 332-340.

[17] Mikulski, D., J. Jankowski, J. Nackmanski, M. Mikulska, V. Demey. 2012. Effects of dietary probiotic (Pediococcus acidilactici) supplementation on performance, nutrient digestibility, egg traits, egg yolk cholesterol, and fatty acid profile in laying hens. Poultry Science 91 (10): 2691-2700.

[18] Lallemand, B. 2019. Supporting egg quality through feed solutions. World Poultry Vol. 32 No. 10. pp. 35-37.

[19] Suswoyo, I. dan Rosidi. 2016. Welfare and Egg Production of Local Ducks Fed Diets Containing Two Probiotics in Commercial Farms. International Jou. of Poul. Science Volume 15, Number 6, 235-239.

[20] Suswoyo, I., Ismoyowati, W. Widodo, and Z. Vincēviča-Gaile. 2021. The Use of Probiotic and Antioxidants to Improve Welfare and Production of Layer Duck at Commercial Farms for Global Warming Mitigation. E3S Web of Conferences 226, 00025 (2021).

[21] Balkan, M. and M Biricik. 2008. Main Egg Characteristics In The Peking Duck (Anas platyrhynchos f. dom.). D.Ü.Ziya Gökalp Eğitim Fakültesi Dergisi 11, 142-150.

[22] Suswoyo, I., Ismoyowati. 2021. Study on Duck (Anas Plathyrhinchos) Welfare under Extensive and Intensive Systems of Production. International Jou. of Current Research 13 (2): 16047-16049.

[23] Sjofjan, O., DN. Adli, MM Sholikin, A. Jayanegara, A. Irawan. 2021. The effects of probiotics on the performance, egg quality and blood parameters of laying hens: A meta-analysis. J. Anim. Feed Sci. 2021;30(1):11-18.

[24] Caly, D.L., D Inca, R., Auclair, E., Drider, D. 2015. Alternatives to antibiotics to prevent necrotic enteritis in broiler chickens: A microbiologist's perspective. Front. Microbiol 6, 1336.

[25] Zurmiati, M. E. Mahata, M. H. Abbas, Wizna. 2014. The Aplication of Probiotic on Duck (In Indonesian Language). Jurnal Peternakan Indonesia Vol. 16 (2).

[26] Ministry of Agriculture. 2019. The use of antibiotic in Chicken. Center for Agricultural Extensions. Jakarta.

[27] Nurjannah, S Yanto, Patang. 2017. Utilization of Golden Snail (Pomacea Canaliculata L) and Waste Crab Shell (Portunus Pelagicus) To Animal Feed For Increase The Production of Egg's Duck. Jurnal Pendidikan Teknologi Pertanian, Vol. 3 (2017) : 137147.

[28] Bidura, IGNG., NW Siti, DPMA Candrawati, E Puspani. 2019. Effect of Probiotic Saccharomyces spp. on Duck Egg Quality Characteristics and Mineral and Cholesterol Concentrations in Eggshells and Yolks. Pakistan Journal of Nutrition, 18: 1075-1083.

[29] Yurlahmen, R. 2008. Performa Ayam Petelur Umur 21-27 Minggu Yang Diberi Air Rebusan Daun Sirih (Piper Bettle Linn) Pada Air Minum. Progam Studi Ilmu Nutrisi Dan Makanan Ternak Fakultas Peternakan IPB. Bogor.

[30] de Lima, MR., FGP Costa, EB de Oliveira, RGS Deminicis, DS do Nascimento, TS Ribeiro. 2017. Alternatives to the use of antibiotics in egg productions. Open Access $\mathrm{J}$ Sci. (5):145-147. 